asHoka

UNIVERSITY

ASHOKA UNIVERSITY ECONOMICS

DISCUSSION PAPER NO. 41

Firm Indebtedness, Deleveraging and Exit: The Experience of Slovenia During the Financial Crisis, 2008-2014*

October 2020

Biswajit Banerjee, Ashoka University

Jelena Ćirjaković, Bank of Slovenia

https://ashoka.edu.in/economics-discussionpapers 


\title{
Firm Indebtedness, Deleveraging and Exit: The Experience of Slovenia During the Financial Crisis, 2008-2014*
}

\author{
${\text { Biswajit Banerjee }{ }^{\dagger} \text { and Jelena Ćirjaković }}^{\ddagger}$
}

\begin{abstract}
This paper examines the impact of the global financial crisis on firm exit and corporate deleveraging in Slovenia during 2008-2014 using firm-level data. Firms are classified according to whether they increased their leverage, decreased their leverage or ceased operation during the specified time interval, and the likelihood of being in these three states are estimated. Deleveraging likelihood is analysed separately for total debt, business-to-business debt, bank debt, and non-bank financial debt. This empirical exercise shows that the influence of covariates on firm exit was different from that on deleveraging, and the impact on deleveraging differed between different types of debt.
\end{abstract}

JEL Code: F65

Keywords: Firm indebtedness; Firm deleveraging; Firm exit; Financial crisis; Slovenia

\footnotetext{
*Earlier versions of this paper were presented at a conference on "Challenges for Debt Restructuring and Financing of SMEs" jointly organized by the Bank of Slovenia and European Commission in Ljubljana in September 2015, and at a seminar in Ashoka University, Sonepat, India in January 2017. Comments from Conor O'Toole, Andreja Jaklič, William Greene, and the seminar participants contributed to substantial strengthening of the paper. The views expressed in this paper are those of the authors and do not necessarily represent the views of the institutions to which the authors are affiliated.

$\dagger$ Expert Advisor to the Governor, National Bank of Slovakia, Bratislava, Slovakia; Professor of Economics, Ashoka University, Sonepat, Haryana, India; and Adjunct Senior Fellow, Research and Information System for Developing Countries (RIS), New Delhi, India. Corresponding author. E-mail: bisban50@gmail.com.

$\$$ Section Chief, Financial Stability and Macroprudential Policy Department, Bank of Slovenia, Ljubljana, Slovenia. E-mail: jelena.cirjakovic@bsi.si
} 


\section{Introduction}

It is well documented that corporate sector indebtedness increased substantially in a vast number of countries across the world prior to the emergence of the global financial crisis in 2008 (see, for example, European Central Bank, 2013; Garrote et al., 2013). The onset of the crisis resulted in an abrupt reduction in availability of loanable funds in the wholesale market which had a knock-on effect on the retail market and generated a feedback loop between deleveraging in the financial and non-financial sectors. Heavily indebted distressed enterprises that were still viable adjusted to the shocks through deleveraging and cutting back on their operations. At the same time, a growing number of enterprises ceased operations and exited as the financial and demand shocks rendered them unviable (Banerjee and Jesenko, 2014; Landini et al., 2015). In this paper, we examine corporate deleveraging and firm exit in Slovenia during the period 2008-2014. We study changes in leverage behaviour separately for total debt, business debt, bank debt and nonbank financial debt. The explanatory variables that we consider are similar to those that have been highlighted in the corporate finance literature on capital structure (see Frank and Goyal, 2008; and Graham and Leary, 2011).

The pace and extent of deleveraging in the period under consideration varied across countries and sectors (European Central Bank, 2013; Cuerpo et al., 2015). The deleveraging process triggered by the crisis was driven by a combination of demand and supply factors. The market downturn, a general increase in uncertainty and risks reduced the ability of banks to evaluate the creditworthiness of their clients properly. This, together with rising non-performing loans, prompted banks to tighten lending standards through higher collateral requirements, stoppage of the automatic renewal of loans and enhanced credit rationing. ${ }^{1}$ Besides the forced deleveraging on account of tighter supply-side conditions, enterprises also adjusted their investment plans and capital structure on their own accord in view of the recession and an uncertain economic outlook.

\footnotetext{
${ }^{1}$ Bank lending surveys in the eurozone show that credit conditions became more restrictive from 2008. This survey is addressed to senior loan officers of a representative sample of eurozone banks and is conducted four times a year. Detailed information on the survey and its results are available at http://www.ecb.int/stats/money/surveys/lend/ html/index.en.html.
} 
There were also heterogeneous developments and deleveraging across enterprises, reflecting a process of creative destruction. Financing problems and uncertainty affected individual enterprises with different degrees of intensity during the crisis. While unviable enterprises ceased operations and exited, distressed but still viable ones deleveraged and cut back on their operations. At the same time, many less-indebted enterprises increased their leverage and carried out investment despite a worse macroeconomic outlook and an overall deleveraging trend by firms. (European Central Bank, 2013; IMAD, 2014; Iqbal and Kume, 2014). In addition, new firms continued to enter the market during the crisis, though at a slower pace than in the precrisis period.

There is a growing literature on the impact of the crisis on corporate financing decisions and firm exit. $^{2}$ The focus of these studies is on estimating the change in leverage and the survival rate of enterprises, and examining how the influence of the various determinants of leverage and firm exit changed during the crisis. ${ }^{3}$ A proper understanding of the changing influence of these determining factors is important in order to identify the vulnerabilities that arise from corporate financing challenges, assess the macroeconomic consequences of the adjustment process, ascertain possible drawbacks in policy following the onset of the crisis, and design appropriate policy responses to contain the negative impact of the crisis. ${ }^{4}$ Assessment of the effectiveness of policy measures aimed at enhancing access to credit ought to take into consideration the heterogeneity that exists among firms.

In this paper, we examine corporate deleveraging and firm exit in Slovenia during the period 2008-2014, using firm-level data maintained by the Agency for Public Legal Records and Related Services (AJPES). The chosen time interval covers the period from the onset of the financial crisis till the beginning of economic recovery in Slovenia. Unlike other studies mentioned in footnote 2 and reviewed in Section 2, we do not estimate the determinants of the level of or change in leverage. Instead, we categorize firms on the basis of whether they increased their leverage, decreased their leverage or ceased operations during the specified time

${ }^{2}$ See Section 2. Notable studies are Bole et al. (2014), Demirguc-Kunt et al. (2015), European Central Bank (2013), Herwadkar (2017), Iqbal and Kume (2014), van Doornmalen (2013), Teixeira and Pereira (2016) and Tripathy and Asija (2017).

${ }^{3}$ The different ways in which earlier studies have examined the impact of the financial crisis on firm leverage is noted in Section 2 below.

${ }^{4}$ A conclusion of Bole et al. (2014) is that policy mistakes by bank regulators in Slovenia prolonged the duration of the post-crisis credit crunch. 
interval, and analyse the determinants of the probability of increasing leverage, decreasing leverage and exit. To the best of our knowledge, we are not aware of other studies that have taken this approach to look into the impact of the crisis on leverage. Another distinctive feature of our paper is that we study changes in leverage behaviour separately for total debt, business-tobusiness debt, bank debt and non-bank financial debt. Such an exercise is important because of likely variations in leverage behaviour by type of debt. As the European Central Bank (2013) has pointed out, in conditions of tighter credit standards and lower risk appetite of banks during the financial crisis, firms in many eurozone countries tended to substitute bank loans with other debt financing sources, such as inter-company loans and debt securities.

Slovenia is an interesting case study because the indebtedness of Slovenian firms increased at a rapid pace after the country joined the European Union in May 2004, and the corporate debt-toGDP ratio rose above that of the eurozone average in mid-2008. ${ }^{5}$ The onset of the global financial crisis in 2008 hit Slovenia particularly hard. The recession that followed was one of the most severe in the eurozone, with the second largest cumulative drop in GDP after Greece. Economic recovery began on a sustained basis only from mid-2013 but was "credit-less" until 2016. Bank credit growth slowed sharply with the onset of the crisis, turned negative in 2011 and remained so until 2016. Overall corporate net financing flows were also negative during 20112016, and there was a corresponding rapid decline in the ratio of aggregate corporate debt stock to GDP.

Earlier studies on Slovenia have not examined in a multivariate context the factors that influenced the leverage level or change in leverage during the crisis period. Bole et al. (2014) provide a lucid description of the process of debt accumulation by Slovene firms during the precrisis period and the credit crunch that followed the onset of global financial crisis. ${ }^{6}$ They also examine the determinants of cash flow migration, including bankruptcy. Damijan (2017) looks at the impact of leverage on productivity, employment, exports, investment, and firm exit during

\footnotetext{
5 For data on variation in corporate debt ratio across the eurozone, see https://www.euro-areastatistics.org/classic/corporates-debt-ratio-in-the-euro-area?lg=en

${ }^{6}$ Also see IMAD (2014), Sila (2015) and Financial Stability Review of the Bank of Slovenia for the years 2009-2016 for the evolution of corporate net financing flows and indebtedness. https://bsi.si/en/publications/financial-stability-review.
} 
the crisis period. Gabrijelčič et al. (2016) focus on the impact of leverage and foreign debt financing on net profits and cash flow of firms before and during the crisis. ${ }^{7}$

A notable finding of the current paper is that there were differences between firm exit and deleveraging with regard to the influences of the covariates. Young and small firms and firms with a higher debt burden prior to the financial crisis were most likely to exit during the crisis period. Profitability, productivity, tangibility and pre-crisis debt-to-assets ratio were all positively linked to deleveraging of total debt by continuing firms, a reflection of debt restructuring by firms in response to the heightened uncertainty and risk associated with the crisis. Another key finding of this paper is that the impact of the covariates on deleveraging differed considerably between different types of debt. Thus, there were differences in the pattern of influence of firm size, and the pattern of sectoral influence was less evident for business-tobusiness debt than for bank debt and non-bank financial debt. Tangibility was not significantly related to deleveraging of business-to-business debt and bank debt but was negatively associated with the likelihood of non-bank financial debt leveraging.

The findings have important policy implications. First, the existence of considerable heterogeneity across firms with regard to the impact of the crisis needs to be taken into account in designing policy measures. In this regard, attention should be given to improving access to finance for viable young and small firms. Second, deleveraging by firms with a high debt burden is symptomatic of balance sheet adjustment. Thus, economic policies should avoid contributing to a delay in the balance sheet adjustment by boosting bank credit growth via softening of lending standards. Instead, the authorities could facilitate the exit of nonviable firms through strengthened bankruptcy laws and insolvency procedures, and coordinate orderly restructuring of bank debt. Third, given that enterprises were shifting towards funding from non-bank financial sources, the authorities should monitor the lending of non-bank financial institutions closely.

The rest of the paper is organized as follows. Section 2 contains a selected review of recent studies that have examined the impact of different variables on corporate leverage during the financial crisis and the factors that influenced firm exit. Section 3 describes the data and provides descriptive statistics, including the evolution of firm indebtedness in Slovenia according to type

\footnotetext{
${ }^{7}$ Bojnec and Xavier (2007) estimated the determinants of firm exit in Slovenian manufacturing during the pre-crisis period.
} 
of debt and firm size. Section 4 lays out the methodology for multivariate analysis of factors that influenced deleveraging and firm exit during the crisis period. Section 5 presents the findings of the econometric exercise on changes in leverage behaviour and firm exit during the crisis period. Section 6 then offers the conclusions of this work.

\section{Selected literature review}

\section{Determinants of corporate leverage}

The corporate finance literature on the factors influencing capital structure and leverage of firms is extensive and well documented (see Frank and Goyal, 2008; and Graham and Leary, 2011). An important aim of empirical studies has been to test which of the two theoretical constructsnamely, the "pecking-order" theory and "trade-off theory"-is best supported by data. The pecking-order theory states that firms have a preference order of financing sources, led by internal sources, followed by debt and then equity (Myers, 1984; and Myers and Majluf, 1984). The ordering is influenced by asymmetric information, agency conflicts and associated costs and risks. According to the trade-off theory, firms seek to obtain the optimum capital structure by balancing the benefits and costs of additional debt (Kraus and Litzenberger, 1973). The benefits of additional debt arise from tax deductions for interest payments and mitigation of agency problems, while costs include the costs of potential financial distress. Both theories can be viewed as part of a much broader set of factors that determine the capital structure of a firm. While much of the empirical literature includes firm-specific factors and sectoral variables to explain corporate leverage, cross-country studies also highlight the importance of countryspecific macroeconomic and institutional factors (see, for example, Borio, 1990; and Rajan and Zingales, 1995).

In this section we review the findings of selected recent studies that have specifically sought to examine the impact of the financial crisis on the drivers of corporate leverage. Five of these studies are in a cross-country setting and two are on individual countries. The studies examine the impact of the financial crisis on firm leverage in three different ways: (i) estimating an equation for the entire sample period in which the explanatory variables include, inter alia, a dummy variable for the crisis period; (ii) estimating separate equations for the pre-crisis and crisis periods and further determining, by including slope and intercept dummies for the crisis 
period, if the covariates had different levels of influence on leverage following the onset of the crisis; and (iii) estimating an equation in which the dependent variable is the change in leverage ratio during the crisis period. Although the time interval of the crisis period varies across the studies, there is considerable overlap. ${ }^{8}$

\section{Dummy variable for crisis period and leverage}

Demirguc-Kunt et al. (2015), Iqbal and Kume (2014), Teixeira and Pereira (2016), and van Doornmalen (2013) estimate an equation for the entire sample period in which the explanatory variables include a dummy variable for the crisis period. The time interval for the crisis dummy is 2008-2009 in the studies by Demirguc-Kunt et al. and Iqbal and Kume, and 2007-2009 in the study by Teixeira and Pereira. In the study by Van Doornmalen the crisis period covers the intervals 2008Q1-2009Q2 and 2011Q3-2012Q4. Both Demirguc-Kunt et al. and Iqbal and Kume also include a second dummy variable in the regression equation for the post-crisis period covering the interval 2010-2011.

The findings are mixed and sample dependent. Demirguc-Kunt et al. (2015) find that in the equation for all firms in the sample the dummies for both the crisis and post-crisis periods were not statistically significant. However, when the sample was restricted to a subset of firms with positive pre-crisis long-term debt, both the crisis and post-crisis dummies were negative and significant, and the reduction of leverage was much larger during the post-crisis period. Demirguc-Kunt et al. consider these results as an indication that inclusion of firms with zero long-term debt in the sample tends to bias the estimates downward. The authors also note that there were differences in leverage behaviour across income groups: a significant decline in leverage occurred during the crisis period for firms in the middle income and low income countries, and for firms in high income countries that did not experience a crisis.

\footnotetext{
${ }^{8}$ Demirguc-Kunt et al. (2015) analyse firm-level data for 79 countries over the period 2004-2011; the European Central Bank (2013) examines firm data for 17 countries spanning the period 2001-2010; Herwadkar (2017) focuses on 10 major emerging market economies for the period 1996-2014; Iqbal and Kume's (2014) study consists of firms from UK, France, and Germany covering the 2006-2011 period; van Doornmalen (2013) examines quarterly data for 1999-2012 on nonfinancial firms in France, Germany, Netherlands, and UK; Teixeira and Pereira (2016) look at data on Portugal for the period 20002009; and Tripathy and Asija (2017) study a sample of nonfinancial firms in India covering the period 2003-2014.
} 
In contrast, Teixeira and Pereira (2016) for Portugal and van Doornmalen (2013) for a pooled sample of four western European countries obtain a positive and significant coefficient for the crisis period, suggesting that the leverage ratio of firms went up in these countries during this period, even after controlling for time-varying changes in factors affecting capital structure. ${ }^{9}$ Iqbal and Kume (2014) also found that leverage ratios were significantly higher during the crisis period for the full sample of UK and German firms, but not for the French sample. However, they point out that the pattern was different between the subsample of conservative firms (precrisis leverage ratios lower than the industry mean) and aggressive firms (pre-crisis leverage ratios higher than industry mean). The leverage ratios for conservative firms increased significantly during the crisis and post-crisis periods across the three countries. For aggressive firms, the leverage ratio declined significantly during the crisis period only for the French sample, but for the post-crisis period the leverage ratio was significantly lower in all three countries.

Subsample analysis to determine changes in the impact of the driving factors of leverage during the crisis period

The European Central Bank (2013) and Iqbal and Kume (2014) estimate equations for the entire sample period in which each of the explanatory variables are interacted with the crisis period dummy to determine if there were significant changes during the crisis period in the impact of the covariates on leverage. Herwadkar (2017), Teixeira and Pereira (2016), and Tripathy and Asija (2017) estimate separate equations for the pre-crisis and crisis periods but do not test if the coefficients for the two periods were significantly different. Nevertheless, conclusions can be still drawn if the signs and significance of the coefficients had changed between the pre-crisis and crisis periods. We review below the findings of these studies on the standard firm-level determinants of capital structure, and relate them to the predictions of the pecking-order and trade-off theories.

\footnotetext{
9 The European Central Bank (2014) notes that even after the outbreak of the financial crisis, debt-toGDP ratios of eurozone non-financial corporations in the aggregate continued to increase, peaking in 2009-2010. The study sees this as a reflection of a "normal" pattern of somewhat delayed debt deleveraging, mainly related to the lagging pattern of bank credit around turning points in economic activity. The rising leverage ratio is also explained by a sharp contraction in real GDP (i.e., the denominator effect).
} 
Profitability. With the exception of the firms in Iqbal and Kume's (2014) sample for the UK and Germany, all the studies obtained a significant negative relationship between profitability and leverage, in line with the prediction of the pecking-order theory that firms prefer to finance with retained earnings rather than external finance. For all three European countries studied by Iqbal and Kume, there was no significant change in the strength of the impact of profitability on leverage during the crisis period. However, in the studies by the European Central Bank (2013) on eurozone countries, Teixeira and Pereira (2016) on Portugal and, Tripathy and Asija (2017) on India the negative relationship was weaker during the crisis period, suggesting that leverage at higher level of profits was greater during the crisis period compared to the pre-crisis period. In contrast, Herwadkar (2017) examines firms in 10 emerging market economies and finds that the negative relationship between profitability and leverage was stronger during the crisis period, implying that firms at higher levels of profits were less leveraged during the crisis period compared to the pre-crisis period.

Liquidity. The European Central Bank (2013) for eurozone countries and Teixeira and Pereira (2016) for Portugal find a negative relationship between liquidity and leverage which became stronger during the crisis period. Looking at India, Tripathy and Asija (2017) find that the relationship between liquidity and leverage was not statistically significant during the pre-crisis period but that, in line with the findings of the European Central Bank (2013) and Teixeira and Pereira (2016), it became significantly negative during the crisis period. A negative relationship between liquidity and leverage may be expected if the agency cost of debt is higher than the opportunity cost of retaining earnings. If firms face financing constraints, they may decide to hold more cash to hedge against the possibility of falling short of resources in the future. Also, as Myers and Rajan (1998) have argued, greater asset liquidity can in some circumstances reduce a firm's capacity to raise external finance. The European Central Bank (2013) study suggests that the reduced availability of liquid assets during the crisis made their negative effects on leverage relatively more important.

Tangibility. The evidence is mixed. For all the three European countries studied by Iqbal and Kume (2014), there was a significant positive relationship between tangibility and leverage during the pre-crisis period, and there was no significant change in the strength of the impact during the crisis period. The European Central Bank (2013) and Tripathy and Asija (2017) also 
find a significant positive relationship between tangibility and leverage during the pre-crisis period, but the impact became more limited during the crisis period. This positive relationship is explained by the trade-off theory in terms of high tangibility reducing expected financial distress costs and mitigating debt-related agency problems (see Frank and Goyal, 2009; and Rajan and Zingales, 1995). A weakening of the positive relationship during the crisis period suggests that creditors tightened their lending standards and increased the collateral requirements. The findings of Teixeira and Pereira (2016) also indicate that firms with more tangible assets lowered their leverage ratios during the crisis period. The coefficient on tangibility in their study was not statistically significant in the pre-crisis period but turned significantly negative during the crisis. In contrast, the results of Herwadkar (2017) for a sample of emerging market economies suggest that the debt issuing conditions were lucrative for all firms during the crisis period, irrespective of their levels of holding of tangible assets. He found that while tangibility had a significant negative relationship with leverage during the pre-crisis period, in line with the prediction of the pecking-order theory, tangibility ceased to be a significant determinant of corporate leverage in the crisis period.

Firm size. All the studies included in this literature review, except for Herwadkar (2017), find a significant positive relationship between firm size and leverage during the pre-crisis period, but the findings on the impact of size during the crisis period differed across the studies. The tendency of larger firms to have greater leverage is generally explained in the literature in terms of information asymmetry and default risk being smaller for larger firms. The European Central Bank (2013) study and Teixeira and Pereira (2016) find that differences owing to firm size became smaller during the crisis, suggesting that larger firms reduced their leverage more than small firms in the crisis period. Consistent with this, although in a more exaggerated form, Tripathi and Asija (2017) report that size was not significantly related to leverage in the crisis period, whereas the relationship was positive and significant during the pre-crisis period. In contrast, Iqbal and Kume (2014) detect no significant change in the relationship between firm size and leverage on account of the crisis. At the other extreme, Herwadkar (2017) find no significant effect of firm size on leverage during the pre-crisis period, but the relationship turned out to be positive and significant during the crisis, implying that larger firms became more leveraged in the crisis period. 
Firm age. The European Central Bank (2013) study as well as Teixeira and Pereira (2016) found that younger firms were more leveraged than older firms during the pre-crisis period. This is in line with the prediction of the pecking-order theory which argues that the longer track record of older firms enables them to issue equity more easily than younger firms (Frank and Goyal, 2009). The negative relationship between firm age and leverage persisted during the crisis period for the overall sample of firms in eurozone countries, but the differences between the leverage of younger firms and more mature firms widened. In contrast, the pattern was opposite for the sample of Portuguese firms considered by Teixeira and Pereira. In their study, the relationship between firm age and leverage switched signs and turned positive during the crisis period, indicating that younger firms in Portugal were more severely impacted by the crisis than older firms with regard to debt financing.

Growth opportunities. The European Central Bank (2013) study and Teixeira and Pereira (2016) both obtain a positive significant relationship between growth opportunities and leverage for the pre-crisis and crisis periods, but the strength of the impact weakened during the crisis period. A positive relationship supports the pecking order theory, which implies that firms with more investments are likely to accumulate more debt over time. The relationship weakened owing to the increase in uncertainty during the crisis period. In contrast, Iqbal and Kume (2014) find that the crisis did not have any significant influence on the relationship between growth opportunities and leverage of firms in France, Germany, and the UK.

\section{Determinants of changes in the leverage ratio during the crisis period}

Demirguc-Kunt et al. (2015) estimate a cross-sectional empirical model in which the change in the leverage ratio is regressed on the initial pre-crisis leverage, initial firm characteristics, and changes in the firm-specific control variables during the crisis period. They found that firm-level initial conditions played an important role in explaining the cross-sectional changes in leverage. In particular, they observed that firms with a higher initial debt burden and higher initial profit reduced their leverage during the crisis. The initial level of tangibility had a significant positive impact on the change in the long-term debt to total assets ratio, but no significant impact on the change in the total debt to assets ratio. In addition, larger firms and firms that expanded in size following the onset of the crisis increased their leverage during the crisis. 


\section{Determinants of firm exit}

The determinants of firm exit and survival have received considerable attention in the literature on the capital structure of firms and industrial organization (see, for example, Dunne et al., 1988; Frank and Goyal, 2009; and Santarelli and Vivarelli, 2007). Studies on corporate capital structure point to high leverage and financial constraints as important determinants of firm exit. Those on industrial dynamics see firm entry and exit as a manifestation of innovation and the adoption of new technologies, a process by which productive firms grow while inefficient firms exit. One theory stresses the selection effects associated with passive learning about initial conditions. According to this theory, firms face ex-ante uncertainty about their cost parameters or efficiency level, but accumulate relevant information over time through the process of production, on the basis of which they then decide whether to exit or remain (Jovanovic, 1982). This strand of literature suggests that firm exit is negatively related to firm size and age. Empirical studies (e.g., Fort et al., 2013) have also documented that young, small firms are cyclically more sensitive than large and mature firms.

In the following paragraphs we review the findings of three recent studies on two European countries that specifically examine the impact of the financial crisis on firm exit and survival. The durations of the crisis period considered in these studies overlap but do not match exactly. Bole et al. (2014) look at the determinants of bankruptcy in Slovenia during the crisis period covering 2007-2011, with special emphasis on the role of cash flow and debt leverage. In a similar fashion, Landini et al. (2015) estimates the effect of the drivers of firm exit in the manufacturing sector in Italy during the period 2008-2014. In contrast, Damijan (2017) compares the influence of various drivers of firm survival in Slovenia during both the pre-crisis (2002-2008) and crisis periods (2009-2012).

Outstanding leverage. For Slovenia, Bole et al. (2014) find that the probability of moving to bankruptcy during the crisis period was positive for inter-company debt and negative for financial debt. However, Damijan (2017) reports that the total debt leverage did not have any significant effect on firm survival in Slovenia, either before or during the crisis period, a finding that applied to firms of all sizes. He attributes this to the complexity and inefficiency of the past insolvency procedures in Slovenia that were focused on protecting the rights of firm owners over the rights of major creditors. Landini et al. (2015) do not have a direct measure of the debt 
leverage in their study on Italy, but include a measure of the financial situation defined by FINEXP $=$ [(liabilities - net assets - credits $) /$ net assets $]$ in 2007. They find, in contrast to the findings for Slovenia by Bole et al. and Damijan, a positive significant relationship between FINEXP and the probability of exit.

Interest coverage ratio. Damijan (2017) includes the interest coverage ratio as an explanatory variable to complement the debt leverage variable in order to determine the sustainability of a firm's interest payments burden. He finds that a firm's ability to service interest payments had no significant impact on firm survival during the pre-crisis period, but became positive and highly significant in the time of crisis.

Profitability. In line with expectations, Landini et al. (2015) find that in the Italian manufacturing sector a higher rate of return on assets was associated with a lower probability of firm exit during the crisis period. However, for Slovenia, Damijan (2017) reports a uniform and significant negative effect of return on equity on firm survival for both the pre-crisis and crisis periods, but does not offer any explanation for this unexpected result. Bole et al. (2014) do not consider the role of profitability in their study, but examine the influence of cash flow from current operations and find that a higher cash flow decreased the probability of bankruptcy.

Liquidity. Damijan (2017) find that in Slovenia liquidity (defined as the ratio of short-term assets to short-term liabilities) was positively associated with firm survival and that the effect became stronger during the crisis period. In contrast, in the study of Italian firms by Landini et al. (2015), liquidity (defined as ratio of liquid assets to net assets) turned out to be not significant in explaining firm exit during the crisis period considered as a whole. However, liquidity was a more important determinant of firm exit late in the crisis period than in the immediate aftermath of the crisis, suggesting that availability of adequate liquid resources becomes relevant for coping with a prolonged recession.

Firm size. Bole et al. (2014) find that the firm size had only a weak influence on the probability to migrate to bankruptcy during the crisis period in Slovenia. The coefficients were not statistically significant for most size groups, except for firms with no employees in 2009 (positive effect on bankruptcy) and firms with 2 to 5 employees in 2010 and 2011 (negative effect on bankruptcy). In contrast, Damijan (2017) finds a significant negative relationship for 
the entire sample period between firm employment and probability of survival; that is, the probability of firm exit increased with firm size. However, in the separate regressions for firm size classes, Damijan finds that the degree of negative impact of the crisis on firm survival was broadly similar for micro, small and medium-sized firms. The coefficient of the crisis dummy was not statistically significant for large firms. However, Damijan does not comment on or offer an explanation for these contrasting findings.

The evidence for Italy on the role of firm size is broadly similar to that obtained for Slovenia. Landini et al. (2015) find that firm size was not a significant factor in explaining firm exit during the crisis. In their view, this suggests that age is not a characteristic that differentiates among firm responses in the presence of negative and unexpected macroeconomic shocks.

Other variables. For Slovenia, Bole et al. (2014) note that the likelihood of migrating to bankruptcy was higher for firms in the construction sector. Damijan (2017) observes that firms with higher labour productivity, state-controlled firms and exporters displayed higher probability of survival during the entire sample period, but he does not report the significance of the crisis dummy interaction terms on these variables. For Italy, Landini et al. (2015) find that labour productivity, firm age, and none of the export-related indicators were significant in explaining firm exit. They consider the last two results puzzling in view of the international nature of the financial crisis and the emphasis that is usually placed in the literature on firm age as a driver of survival. They speculate that these results may be due to the relatively long time span chosen to define the crisis period. A notable contribution of Landini et al.'s study is that they show that intangible assets significantly reduce the probability of firm exit.

\section{Data and descriptive statistics}

The analysis in this paper is based on annual firm-level data from the Business Register of Slovenia and the Annual Reports of Corporate Entities that are collected by AJPES. The database pertains to all private business entities, their subsidiaries, and other organizational segments, which perform profitable or non-profitable activities. Enterprises (including insurance companies, investment funds, and co-operatives), sole proprietors, legal entities governed by public law, and non-profit organizations have to submit their annual reports to AJPES for the purpose of presenting them publicly and for tax and statistical purposes. The AJPES database 
includes information on firms' financial statements, full-time-equivalent (FTE) employment, industrial affiliation, location, and year of incorporation in the business register. The analysis in this paper is confined to non-financial firms that have at least one FTE employee. The data set comprises between 28,000 and 41,500 annual observations on firms over the period 2004 to 2017. Annual data on the total number of firms disaggregated by the number of continuing firms, new entrants, and exiting firms, and the number of continuing firms that had deleveraged, are shown in the Appendix.

\section{Firm entry and exit}

Since each firm in the data set has a unique identification code, we are able to observe the entry and exit of firms each year. ${ }^{10}$ Simultaneous firm exit and entry is a routine phenomenon in the corporate sector, and is indicative of firm-level heterogeneity and differential responses to sectoral and macroeconomic shocks. The firm exit rate in Slovenia increased in the aftermath of the financial crisis to a peak of 17 percent in 2012. The shake out of firms decreased in the subsequent years, but remained at a level higher than during the pre-crisis period. In contrast, the rate of entry of new firms decreased only slightly following the onset of the financial crisis but rose sharply during 2013-2014, coinciding with the beginning of economic recovery, and declined thereafter to the pre-crisis levels (Figure 1).

A picture of the cumulative dimensions of firm exit and entry from the onset of the financial crisis until the beginning of economic recovery is provided by the changes in the existence status of firms between 2008 and 2014. About 37 percent of the firms that were in existence in 2008 were no longer in business in 2014. In contrast, 42 percent of the firms that were in existence in 2014 had entered the market since 2008. The rate of both exit and entry was inversely related to firm size - it was highest among micro firms and least among large firms. The rate of exit was lower among firms that had bank debt. The proportion of firms that exited from business during 2008-2014 was highest among firms in construction and real estate and lowest among firms in manufacturing (Table 1).

\footnotetext{
${ }^{10}$ A firm is considered to have exited in a particular year if it did not report data that year but had done so in the previous year. A firm is deemed to have entered business in a particular year if it started to report data that year but had not done so in the previous year.
} 
Figure 1: Firms entry and exit rates, 2005-2017

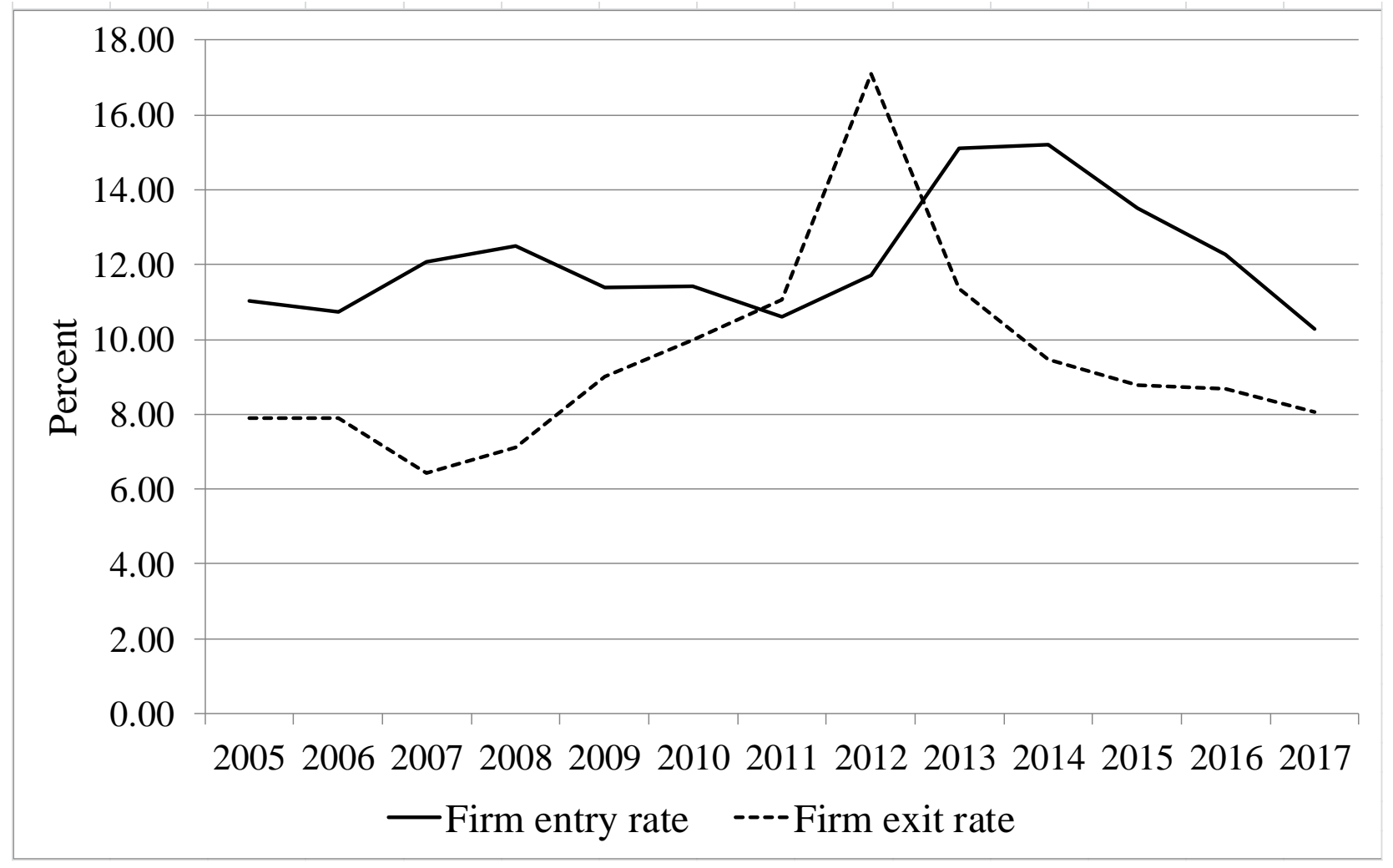

Source: AJPES; authors' calculations.

Leverage by firm size and type of debt

Virtually all firms had debt. The recourse to business-to-business debt (i.e., mainly trade credits and inter-company loans) debt was universal. However, the prevalence of financing from banks and non-bank financial institutions increased with firm size, with a considerable gap between micro firms and the larger size groups. Among small, medium-sized and large firms, a higher proportion relied on bank debt than on non-bank financial debt. Many firms availed of financing from both banks and non-bank financial institutions, and numerous firms relied on bank or nonbank financial debt only. Reflecting the pattern of overlap in the reliance on both financing sources, the proportion of firms having financial debt was broadly similar among small, mediumsized and large firms (Table 2). 
Table 1. Changes in existence and deleveraging status of firms during 2008-2014

A. Existence and deleveraging status in 2014 of firms that existed in 2008

(in \% of number of firms in 2008)

\begin{tabular}{|c|c|c|c|c|c|c|c|c|}
\hline Status in 2014 compared with 2008 & All firms & Micro firms $^{1}$ & $\begin{array}{l}\text { Small } \\
\text { firms }\end{array}$ & $\begin{array}{l}\text { Medium- } \\
\text { sized firms }\end{array}$ & Large firms & $\begin{array}{c}\text { Firms with } \\
\text { business } \\
\text { debt in } \\
2008\end{array}$ & $\begin{array}{l}\text { Firms with } \\
\text { bank debt } \\
\text { in } 2008\end{array}$ & $\begin{array}{c}\text { Firms with } \\
\text { non-bank } \\
\text { financial } \\
\text { debt in } \\
2008\end{array}$ \\
\hline Continuing firms & 62.8 & 61.0 & 74.6 & 77.2 & 81.0 & 62.8 & 71.6 & 70.8 \\
\hline Firms that did not deleverage & $(24.4)$ & $(24.6)$ & $(21.9)$ & $(23.0)$ & $(30.8)$ & $(25.7)$ & $(28.4)$ & $(44.2)$ \\
\hline Firms that deleveraged & (38.4) & $(36.5)$ & $(52.7)$ & $(54.2)$ & $(50.2)$ & $(37.0)$ & $(43.2)$ & $(26.6)$ \\
\hline Firms that exited & 37.2 & 39.0 & 25.4 & 22.8 & 19.0 & 37.2 & 28.5 & 29.2 \\
\hline Total & 100.0 & 100.0 & 100.0 & 100.0 & 100.0 & 100.0 & 100.0 & 100.0 \\
\hline$(\mathrm{N}$ in 2008$)$ & 33,794 & 29,794 & 2,617 & 1,052 & 331 & 33,794 & 16,203 & 21,040 \\
\hline Status in 2014 compared with 2008 & Manufacturin & Construction & Trade & $\begin{array}{c}\text { Transport } \\
\text { and } \\
\text { storage }\end{array}$ & $\begin{array}{l}\text { Accommodation } \\
\text { and food } \\
\text { services }\end{array}$ & Real estate & Others $^{2}$ & \\
\hline Continuing firms & 72.4 & 45.3 & 63.5 & 62.4 & 55.7 & 53.9 & 66.3 & \\
\hline Firms that did not deleverage & $(25.9)$ & $(18.2)$ & $(24.3)$ & $(20.5)$ & $(27.9)$ & $(23.5)$ & $(26.4)$ & \\
\hline Firms that deleveraged & (46.5) & $(27.1)$ & $(39.2)$ & $(41.8)$ & $(27.8)$ & $(30.4)$ & $(39.9)$ & \\
\hline Firms that exited & 27.6 & 54.7 & 36.5 & 37.6 & 44.3 & 46.1 & 33.7 & \\
\hline Total & 100.0 & 100.0 & 100.0 & 100.0 & 100.0 & 100.0 & 100 & \\
\hline$(\mathrm{N}$ in 2008$)$ & 5,213 & 4,580 & 8,715 & 1,711 & 1,585 & 774 & 11,216 & \\
\hline
\end{tabular}

B. Existence status in 2014 compared with 2008 of firms that existed in 2014

(in \% of number of firms in 2014)

\begin{tabular}{lccccc} 
Status in 2014 compared with 2008 & All firms & Micro firms & $\begin{array}{c}\text { Small } \\
\text { firms }\end{array}$ & $\begin{array}{c}\text { Medium- } \\
\text { sized firms }\end{array}$ & Large firms \\
\hline Continuing firms & 57.8 & 54.8 & 84.0 & 89.6 & 92.7 \\
New firms & 42.2 & 45.2 & 16.0 & 10.4 & 7.3 \\
Total & 100.0 & 100.0 & 100.0 & 100.0 & 100.0 \\
(N in 2014) & 36,712 & 33,193 & 2,324 & 906 & 289 \\
\hline
\end{tabular}

${ }^{1}$ Firms are classified into four size groups (micro, small, medium and large) in accordance with Article 5 of the Companies Act (ZGD-1). The classification is based on satisfying any two of the criteria on number of employees, annual turnover, and value of assets. Micro firms have fewer than ten workers and turnover or assets of less than $€ 2$ million. The corresponding figures for small firms are 50 workers and turnover of less than $€ 8.8$ million or assets of less than $€ 4.40$ million. For medium-sized firms the thresholds are 250 workers, turnover of less than $€ 35$ million and assets of less than $€ 17.5$ million. Above these cut-off points, firms are classified as large.

2 "Others" include NACE categories A, B, D, E, J, K, M, N, O, P, Q, R and S.

Level of leverage. Firms utilized bank loans and financing from other sources to different extents depending on their size. In all years, the largest component of the total debt leverage ratio (defined as ratio of outstanding total debt to total assets) was business-to-business debt leverage. As can be discerned from Figure 2, the median total debt-to-assets ratio was negatively related to firm size. Micro firms were most leveraged while large firms were least leveraged. The negative relationship was the result of the greater importance of business-to-business debt and non-bank financial debt for the smaller firm-size groups. For both these categories of debt, the leverage 
Table 2. Firm indebtedness by firm-size group and type of debt, 2008

(Percent of firms in each size group that had a particular type of debt in 2008)

\begin{tabular}{|c|c|c|c|c|c|}
\hline & \multirow[b]{2}{*}{ Total debt } & \multirow[b]{2}{*}{ Business debt } & \multicolumn{3}{|c|}{ Financial debt } \\
\hline & & & Bank deb & $\begin{array}{l}\text { Non-bank } \\
\text { financial } \\
\text { debt }\end{array}$ & $\begin{array}{l}\text { Financial } \\
\text { debt, total }\end{array}$ \\
\hline All firms & 99.6 & 97.9 & 40.9 & 49.4 & 65.1 \\
\hline Micro firms & 99.6 & 97.9 & 36.6 & 47.4 & 63.2 \\
\hline Small firms & 100.0 & 97.5 & 71.3 & 63.2 & 87.1 \\
\hline Medium-sized firms & 100.0 & 97.4 & 74.2 & 66.5 & 88.1 \\
\hline Large firms & 100.0 & 97.6 & 78.1 & 70.1 & 89.9 \\
\hline
\end{tabular}

Source: AJPES; authors' calculations.

ratio was highest for micro firms and it became smaller as firm size increased. In contrast, the leverage ratio for bank debt was positively related to firm size. Large firms had a higher leverage ratio for bank debt than the other firm-size groups. In addition, large firms were more leveraged with bank debt than with business-to-business debt. This overall pattern is in accordance with the theoretical considerations of the corporate finance literature. Smaller firms tend to be more vulnerable to the problem of information asymmetry as information supplied by them in credit applications is not readily verifiable. In contrast, larger firms have better reputations in debt markets and face lower information costs when borrowing.

Trend in leverage. There was considerable variation in the trend in leverage between firm size groups and types of debt. During the pre-crisis period, the median leverage ratio for total debt increased rapidly for medium-sized and large firms but remained broadly unchanged for micro and small firms. Following the onset of the crisis, the median total debt leverage ratio fell for all size groups, but the decline was more pronounced for small and medium-sized firms. 
Figure 2: Median debt to assets ratio by firm size and categories of debt, 2004-2017
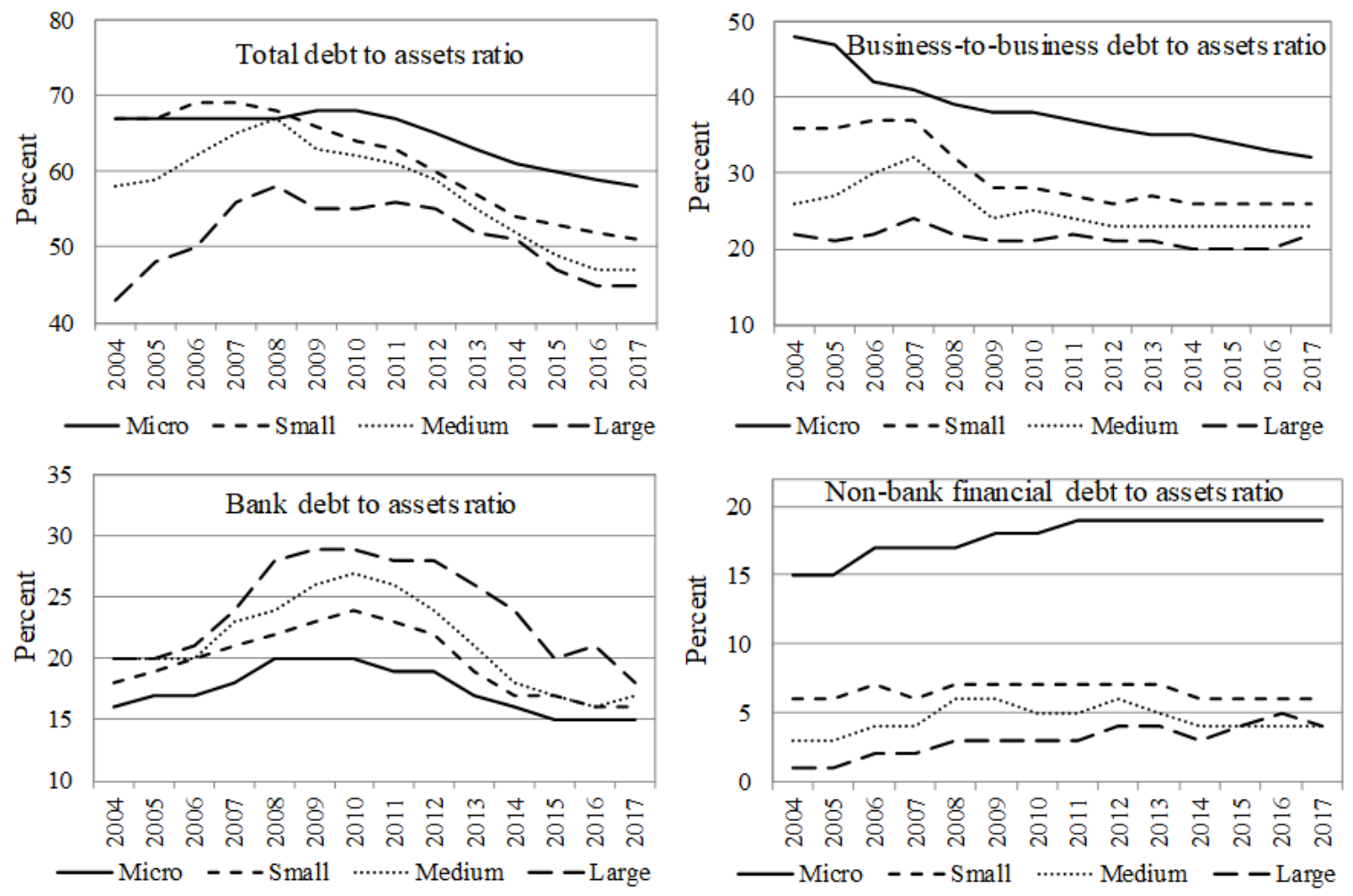

Source: AJPES; authors' calculations.

The median leverage ratio for business-to-business debt for micro firms was already on a declining trend during the pre-crisis period, and this continued following the onset of the financial crisis. This pre-crisis declining trend likely reflects substitution of bank debt and nonbank financial debt for business-to business debt as bank credit conditions became easier. In contrast, the leverage ratio of large firms for business-to-business debt remained broadly stable throughout the pre- and post-crisis periods. For small and medium-sized firms, the leverage ratio for business-to-business debt fell markedly during 2007-2009 and remained flat in the subsequent periods.

For all firm-size groups, the leverage ratio for bank debt increased during the pre-crisis period and decreased following the onset of the crisis. Both the pre-crisis increase and subsequent decline in leverage were greater for medium-sized and large firms. The turnaround in the leverage ratio occurred in different years for the different groups. The onset of the crisis had an almost immediate impact on the bank debt leverage ratio of micro firms, but the declining trend 
for the other size groups appeared with a lag - one year for large firms and two years for small and medium-sized firms.

The leverage ratio of non-bank financial debt for micro firms was on a rising path during the precrisis period and the initial years of the crisis period, but stabilized from 2011 onwards. There was no apparent negative impact of the financial crisis on the leverage of non-bank financial debt for small, medium-sized and large firms. The leverage ratio was broadly stable for small and medium-sized firms, while it was on a mildly rising trend for large firms.

Incidence of leveraging and deleveraging by firms during the crisis period. The dynamics of the median leverage ratio masks the individual behaviour of firms. In particular, although the median leverage ratios for different types of debt and firm-sizes were on a declining path during the crisis period, not all firms deleveraged in response to the financial crisis. As Table 1 shows, about one fourth of the firms that existed in 2008 did not deleverage during the crisis period. The incidence of not deleveraging varied within a narrow range, but was highest for large firms, firms with bank debt, and firms in accommodation and food services activities.

\section{Methodology}

In this paper, we classify firms into three categories: whether they deleveraged, did not deleverage or ceased operations over the period 2008-2014. The analysis of the determinants of the probability of deleveraging and exit is carried out in two ways. First, based on data for all firms in the sample, we examine the probability of firm exit versus continuation of operations by estimating a binary probit model. Second, we look at the probability of deleveraging versus not deleveraging among continuing firms, separately for different types of debt. The regression equations for deleveraging of total debt and business-to-business debt are estimated by fitting a regular probit model, and the regression equations for deleveraging of bank debt and non-bank financial debt are estimated by fitting a probit model with continuous endogenous regressors. The application of a different type of probit model is appropriate in the case of bank debt and non-bank financial debt, because not all continuing firms in the sample had these two categories of debt (whereas virtually all firms had total debt and business-to-business debt) and the regressor measuring the outstanding debt burden prior to the crisis is endogenous and likely to be correlated with the error term. 
The estimated equations are as follows:

$$
Y_{i}=\beta_{0}+\sum_{k} \beta_{k} X_{k i, 2008}+\varepsilon_{i}
$$

where $Y_{i}$ takes the value of 1 if firm $i$ had exited during the period 2008-2014 and 0 otherwise in the binary probit model of firm exit, and takes the value of 1 if firm $i$ had deleveraged during the period 2008-2014 and 0 otherwise in the probit models of deleveraging by continuing firms. $\beta_{0}$ is the constant; $\beta_{k}$ is the parameter estimated by the model for variable $k ; X$ is the vector of explanatory variables; and $\varepsilon_{i}$ is the random error term. All explanatory variables are measured by their pre-crisis values in 2008. ${ }^{11}$ The explanatory variables in the regression equations are similar to those that have been highlighted in the corporate finance literature on capital structure, and are shown in Table 3.

\section{Empirical results}

\section{Firm exit}

The estimates of the probit model of firm exit using data for all firms in the sample are presented in column 1 of Table 4. Overall, the results are broadly consistent with the theoretical models of the corporate finance literature and the findings of many previous empirical studies.

The regression results are in line with the findings of Dunne et al. (1988) and Fort et al. (2013) for the United States, which show that young, small firms are cyclically more sensitive than mature and large firms and are more likely to fail. We find that, in Slovenia, young firms up to 9 years of age were more vulnerable to the financial crisis than older firms and had a higher likelihood of exit, with firms less than five years old being most at risk of exit. The regression results also indicate an L- shaped relationship between firm size and firm exit: the likelihood of exit was highest for micro firms, but there was no significant difference in the likelihood between the subsequent size groups. Our finding of an L-shaped relationship between firm size and the likelihood of exit is different from the pattern obtained in an earlier study on Slovenia by

\footnotetext{
${ }^{11}$ Since we are looking at the change in the state of enterprises during a specified time interval, the model is akin to a cross-sectional model. Measuring the explanatory variables by their values in the pre-crisis period avoids the problem of endogeneity.
} 
Table 3. Definitions of explanatory variables entered in the regression equations ${ }^{1}$

\begin{tabular}{|c|c|}
\hline Firm age & $\begin{array}{l}\text { Number of years in operation since establishment. Classified into four } \\
\text { groups: } 0-4 \text { years, } 5-9 \text { years, } 10-14 \text { years, } 15 \text { years or more. Entered in the } \\
\text { equation as three dummy variables, with the } 15 \text { years or more category as } \\
\text { the base category. }\end{array}$ \\
\hline Firm size & $\begin{array}{l}\text { Classified into four groups - micro, small, medium-sized and large- on the } \\
\text { basis of satisfying any two of the three criteria on number of employees, } \\
\text { annual turnover, and value of assets (see footnote } 10 \text { in the text). Entered in } \\
\text { the equation as three dummy variables, with large firms as the base } \\
\text { category. }\end{array}$ \\
\hline Exporter status & $\begin{array}{l}\text { Classified into four groups-non-exporter, small exporter, medium exporter } \\
\text { and large exporter-depending on the share of exports to sales to other } \\
\text { European Union (EU) countries and non-EU countries. Firms are classified } \\
\text { as a small exporter if the share of exports in sales is less than } 10 \text { percent; a } \\
\text { medium exporter if the share of exports in sales is } 10 \text { percent or more but } \\
\text { less than } 50 \text { percent; and a large exporter if the share of exports in sales is } \\
50 \text { percent or more. Entered in the equation as three dummy variables, with } \\
\text { non-exporters as the base category. }\end{array}$ \\
\hline Ownership status & $\begin{array}{l}\text { Entered in the equation as two dummy variables: state-owned and other } \\
\text { forms of ownership (viz., social, cooperative and mixed ownership). Private } \\
\text { ownership is the base category. }\end{array}$ \\
\hline Industry affiliation & $\begin{array}{l}\text { Entered in the equation as six dummy variables: Manufacturing (NACE } \\
\text { classification C), Construction (F), Wholesale and retail trade (G), } \\
\text { Transport and storage (H), Accommodation and food service activities (I), } \\
\text { and Real estate activities (L). All other activities are grouped together and } \\
\text { constitute the base category. }\end{array}$ \\
\hline Return on assets (ROA) & Measured as the ratio of net operating profit to total assets. \\
\hline Productivity & Total factor productivity (TFP) estimated using the Levinsohn-Petrin method \\
\hline Asset tangibility & Measured as the ratio of tangible fixed assets to total assets. \\
\hline Liquidity & Measured as (current assets - inventories) / short-term liabilities. \\
\hline Debt to total assets & $\begin{array}{l}\text { For the equation on total debt, the variable is measured as the ratio of total } \\
\text { debt to total assets. For the equation on business-to-business debt, the } \\
\text { variable is measured as the ratio of total business-to-business debt to total } \\
\text { assets. For the equation on bank debt, the variable is measured as the ratio } \\
\text { of total bank debt to total assets. For the equation on non-bank financial } \\
\text { debt, the variable is measured as the ratio of total non-bank financial debt to } \\
\text { total assets. }\end{array}$ \\
\hline
\end{tabular}

${ }^{1}$ All variables were measured by their values in the pre-crisis period; i.e. 2008 values.

Damijan (2017). He reports that the negative impact of the crisis on firm exit was broadly similar for micro, small and medium-sized firms and that the crisis had no significant impact on exit by large firms. 
Table 4: Probit estimates of firm exit and deleveraging of different categories of debt ${ }^{1}$

\begin{tabular}{|c|c|c|c|c|c|}
\hline Sample & All firms & $\begin{array}{l}\text { Continuing } \\
\text { firms }\end{array}$ & $\begin{array}{l}\text { Continuing } \\
\text { firms }\end{array}$ & $\begin{array}{l}\text { Continuing } \\
\text { firms }\end{array}$ & $\begin{array}{l}\text { Continuing } \\
\text { firms }\end{array}$ \\
\hline Estimates for likelihood of: & Firm exit & $\begin{array}{l}\text { Deleveraging } \\
\text { of total debt by } \\
\text { continuing } \\
\text { firms }\end{array}$ & $\begin{array}{l}\text { Deleveraging of } \\
\text { business-to- } \\
\text { business debt by } \\
\text { continuing } \\
\text { firms }\end{array}$ & $\begin{array}{l}\text { Deleveraging } \\
\text { of bank debt by } \\
\text { continuing } \\
\text { firms }\end{array}$ & $\begin{array}{l}\text { Deleveraging of } \\
\text { non-bank } \\
\text { financial debt } \\
\text { by continuing } \\
\text { firms }\end{array}$ \\
\hline Dependent variable & $\begin{array}{l}1 \text { if firm } \\
\text { exited; } 0 \text { if firm } \\
\text { continued } \\
\text { operations }\end{array}$ & $\begin{array}{l}1 \text { if firm } \\
\text { deleveraged } \\
\text { total debt; } \\
0 \text { if firm did } \\
\text { not deleverage }\end{array}$ & $\begin{array}{l}1 \text { if firm } \\
\text { deleveraged } \\
\text { business-to- } \\
\text { business debt; } \\
0 \text { if firm did not } \\
\text { deleverage }\end{array}$ & $\begin{array}{l}1 \text { if firm } \\
\text { deleveraged } \\
\text { bank debt; } 0 \\
\text { if firm did not } \\
\text { deleverage }\end{array}$ & $\begin{array}{l}1 \text { if firm } \\
\text { deleveraged non- } \\
\text { bank financial } \\
\text { debt; } 0 \text { if firm } \\
\text { did not } \\
\text { deleverage }\end{array}$ \\
\hline Independent variables & $\begin{array}{r}\text { Coefficient } \\
\text { (robust } \\
\text { standard error) }\end{array}$ & $\begin{array}{r}\text { Coefficient } \\
\text { (robust } \\
\text { standard error) }\end{array}$ & $\begin{array}{r}\text { Coefficient } \\
\text { (robust standard } \\
\text { error) }\end{array}$ & $\begin{array}{r}\text { Coefficient } \\
\text { (robust } \\
\text { standard error) }\end{array}$ & $\begin{array}{r}\text { Coefficient } \\
\text { (robust standard } \\
\text { error) }\end{array}$ \\
\hline & $(1)$ & (2) & (3) & (4) & (5) \\
\hline \multicolumn{6}{|l|}{ Firm age dummies $^{2}$} \\
\hline Age 0 to 4 & $\begin{array}{c}0.3942 * * * \\
(0.0290)\end{array}$ & $\begin{array}{c}0.0055 \\
(0.0370)\end{array}$ & $\begin{array}{c}-0.1286 \text { *** } \\
(0.0372)\end{array}$ & $\begin{array}{c}-0.2742 * * * \\
(0.0291)\end{array}$ & $\begin{array}{c}-0.2496 \text { *** } \\
(0.0301)\end{array}$ \\
\hline Age 5 to 9 & $\begin{array}{c}0.1660 * * * \\
(0.0323)\end{array}$ & $\begin{array}{c}0.0207 \\
(0.0387)\end{array}$ & $\begin{array}{c}-0.1383 * * * \\
(0.0380)\end{array}$ & $\begin{array}{c}-0.0875 * * * \\
(0.0314)\end{array}$ & $\begin{array}{c}-0.1442 * * * \\
(0.0230)\end{array}$ \\
\hline Age 10 to 14 & $\begin{array}{l}-0.0181 \\
(0.0381)\end{array}$ & $\begin{array}{l}-0.0624 \\
(0.0425)\end{array}$ & $\begin{array}{c}-0.1558 * * * \\
(0.0426)\end{array}$ & $\begin{array}{l}-0.0145 \\
(0.0338)\end{array}$ & $\begin{array}{c}-0.0584^{* *} \\
(0.0240)\end{array}$ \\
\hline \multicolumn{6}{|l|}{ Firm size dummies $^{3}$} \\
\hline Micro firms & $\begin{array}{c}0.3221 * * \\
(0.1253)\end{array}$ & $\begin{array}{c}0.2817 * * \\
(0.1357)\end{array}$ & $\begin{array}{c}0.3384 * * \\
(0.1321)\end{array}$ & $\begin{array}{c}0.4106^{* * * *} \\
(0.1174)\end{array}$ & $\begin{array}{c}-0.1853 * * * \\
(0.0483)\end{array}$ \\
\hline Small firms & $\begin{array}{c}0.1632 \\
(0.1272)\end{array}$ & $\begin{array}{c}0.5020 * * * \\
(0.1336)\end{array}$ & $\begin{array}{c}0.4491 * * * \\
(0.1309)\end{array}$ & $\begin{array}{c}0.3346^{* * * *} \\
(0.1154)\end{array}$ & $\begin{array}{c}0.0089 \\
(0.0480)\end{array}$ \\
\hline Medium-sized firms & $\begin{array}{c}0.0669 \\
(0.1348)\end{array}$ & $\begin{array}{c}0.4105^{* * * *} \\
(0.1380)\end{array}$ & $\begin{array}{l}0.2797 * * \\
(0.1338)\end{array}$ & $\begin{array}{c}0.2517 * * \\
(0.1209)\end{array}$ & $\begin{array}{l}-0.0021 \\
(0.0497)\end{array}$ \\
\hline \multicolumn{6}{|l|}{ Exporter status dummies ${ }^{4}$} \\
\hline Small exporters & $\begin{array}{c}-0.3991 * * * \\
(0.0344)\end{array}$ & $\begin{array}{c}0.3030^{* * * *} \\
(0.0374)\end{array}$ & $\begin{array}{c}0.2115^{* * * *} \\
(0.0368)\end{array}$ & $\begin{array}{c}0.0423 \\
(0.0316)\end{array}$ & $\begin{array}{c}0.0822 * * * \\
(0.0230)\end{array}$ \\
\hline Medium exporters & $\begin{array}{c}-0.1566 * * * \\
(0.0392)\end{array}$ & $\begin{array}{c}0.1790 * * * * \\
(0.0452)\end{array}$ & $\begin{array}{c}0.0889^{* *} \\
(0.0445)\end{array}$ & $\begin{array}{c}0.0249 \\
(0.0414)\end{array}$ & $\begin{array}{c}0.0958^{* * * *} \\
(0.0272)\end{array}$ \\
\hline Large exporters & $\begin{array}{c}-0.0864 * * \\
(0.0433)\end{array}$ & $\begin{array}{c}0.2002 * * * * \\
(0.0502)\end{array}$ & $\begin{array}{c}0.0739 \\
(0.0493)\end{array}$ & $\begin{array}{c}-0.1319 * * * \\
(0.0430)\end{array}$ & $\begin{array}{c}0.0280 \\
(0.0259)\end{array}$ \\
\hline \multicolumn{6}{|l|}{ Ownership dummies ${ }^{5}$} \\
\hline State-owned & $\begin{array}{c}-0.6531 * * * \\
(0.2494)\end{array}$ & $\begin{array}{l}-0.0164 \\
(0.2021)\end{array}$ & $\begin{array}{c}0.2119 \\
(0.1973)\end{array}$ & $\begin{array}{l}0.2748 * \\
(0.1561)\end{array}$ & $\begin{array}{c}0.1854 * \\
(0.1026)\end{array}$ \\
\hline Other mixed ownership & $\begin{array}{l}0.1800^{*} \\
(0.0946)\end{array}$ & $\begin{array}{l}-0.1506 \\
(0.1032)\end{array}$ & $\begin{array}{c}0.0561 \\
(0.1030)\end{array}$ & $\begin{array}{c}0.0222 \\
(0.0896)\end{array}$ & $\begin{array}{c}0.1113 * * \\
(0.0440)\end{array}$ \\
\hline
\end{tabular}


Table 4 (continued)

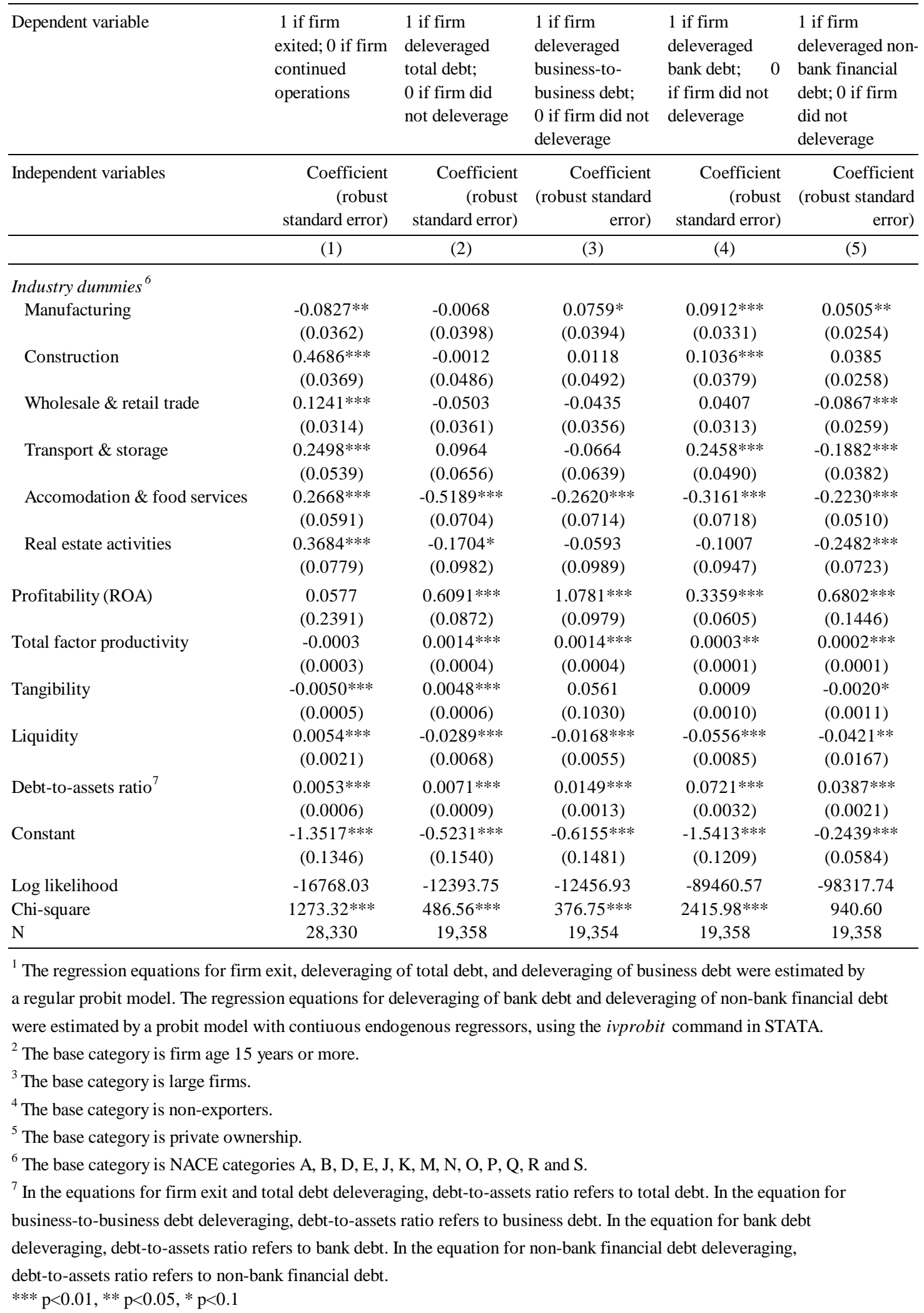


The results show that exporters had a lower likelihood of exit than non-exporters, and that among exporters the likelihood of exit increased as the share of exports in sales increased. The results for exporters versus non-exporters are similar to those of Damijan (2017). ${ }^{12}$ Exporting firms faced two opposing forces during the crisis period. They were likely to be less resource constrained than non-exporting firms because of access to credit from the parent company or suppliers, and a likely better credit rating in the domestic market. ${ }^{13}$ On the other hand, external demand had shrunk considerably during the crisis period, and this uncertainty could have led to disruption in the forward and backward linkages in the supply chain. The results for different categories of exporters suggest that the influence of disruption in the supply chain in Slovenia during the crisis period was likely greater for larger rather than smaller exporters.

We find that likelihood of exit during the crisis period was higher for firms in construction, real estate, accommodation and food services activities, transport and storage, and trade, in that order, and the lowest in the manufacturing sector. This is a reflection of the degree of credit crunch and cash flow constraints felt by these industries and the decline in their demand following the onset of the financial crisis. As noted by Bole et al. (2017), the construction sector in Slovenia experienced a severe drop in the cash flow following the onset of the crisis and the improvement in the situation lagged behind other sectors. We also find that state-controlled firms displayed a lower probability of exit, a reflection of the soft budget constraint and lower bankruptcy risk faced by these firms. Damijan (2017) also reports a similar result.

The financial conditions of Slovene firms at the time of the start of the global financial crisis had a mixed influence on their survival prospect. As per expectations, the likelihood of exit was higher the greater was the initial debt leverage ratio, and lower for higher levels of tangibility. However, contrary to expectations, the likelihood of exit had no significant relationship with profitability and total factor productivity, and was significantly and positively associated with liquidity. It is difficult to explain these contrary results.

Our findings on the influence of profitability and debt burden are in contrast to those obtained for these two variables in an earlier study on Slovenia by Damijan (2017). He obtains a significant

\footnotetext{
${ }^{12}$ However, Damijan (2017) uses only one dummy variable to measure exporter status and does not indicate the export share threshold used to define exporter status.

${ }^{13}$ See Bricogne et al. (2012) for the experience of French exporters and Manova, Wei and Zhang (2015) for that of Chinese exporters.
} 
negative relationship between profitability and firm survival; that is, the likelihood of exit increased with profitability. Damijan (2017) does not comment on this surprising result. He also finds that high financial leverage was not significantly related to firm exit, and that this was equally true for all firm sizes. Damijan (2017) considers this result to be intriguing, and attributes it to the complex and inefficient solvency procedures in Slovenia. However, as noted below in the sub-section on sensitivity of estimates to the measurement of variables, one possible reason for the difference in the findings could be the way that Damijan measures debt leverage. He measured debt leverage as debt-to-EBITDA ratio whereas in this paper we measure leverage as debt-to-assets ratio.

\section{Deleveraging of total debt by continuing firms}

We first report on the findings for deleveraging of total debt by continuing firms because this is the main focus in the literature. Since the results for the deleveraging of total debt represent the combined impact of the various covariates on the deleveraging of business-to-business debt, bank debt and non-bank financial debt, in the subsequent subsections we also discuss and compare the findings for deleveraging of different categories of debt.

A striking feature of the regression results on deleveraging of total debt by firms that continued to operate during the crisis period (column 2, Table 4) is that most of the covariates that were associated with the likelihood of firm exit in a particular direction were associated with deleveraging of total debt in the opposite direction. Thus, covariates that were positively (negatively) associated the likelihood of firm exit were negatively (positively) associated with the likelihood of deleveraging total debt by continuing firms. The influence on firm exit and deleveraging was in the same direction only in the case of two covariates-namely, firm size and initial debt leverage.

There was an inverted U-shaped relationship between firm size and the likelihood of total debt deleveraging. The likelihood of deleveraging initially rose with firm size and subsequently declined as firm size increased. The likelihood of deleveraging was highest for small firms and lowest for large firms. This result is consistent with the findings of Demirguc-Kunt et al. (2015) and Herwadkar (2017) but contrary to the pattern implied by the European Central Bank (2013) and Teixeira and Pereira (2016). The lower likelihood of deleveraging by large firms during the 
crisis period is a reflection of the risk aversion of credit providers. Loanable funds are limited during a financial crisis, and credit providers prefer to lend to larger firms on account of their known reputation and lower default risk.

None of the coefficients on the firm age dummies was statistically significant, suggesting that firms of all age groups faced similar constraints on aggregate debt financing (i.e., all categories of debt considered together) during the crisis period. Firm ownership structure also had no significant influence on deleveraging of total debt. The sectoral influence was much weaker in the case of deleveraging of total debt than in the case of firm exit. Only the coefficients on two sectors - accommodation and food services, and real estate-were statistically significant and had a negative sign, opposite of that observed in the case of firm exit.

Profitability, productivity, tangibility and exporter status were all positively linked to the likelihood of deleveraging total debt. Demirguc-Kunt et al. (2015) and Herwadkar (2017) obtained a similar result on the influence of profitability, but the European Central Bank (2013) study observed a contrary pattern of leverage at higher levels of profits being greater during the crisis period. A positive relationship between profitability and deleveraging supports the hypothesis that heightened economic uncertainty during a crisis clouds investment plans and prompts firms to adjust downward their target leverage ratio. Accordingly, profits are used to repay debt.

One might have expected that because of increased collateral requirements during the crisis period there would be more deleveraging by firms with lower tangibility, but this is not borne out in the regression results. A positive relationship between tangibility and the likelihood of total debt leveraging implies that firms with more tangible assets were disposing assets and using the proceeds to repay debt. This result is similar to that obtained by Teixeira and Pereira (2016) but contrary to the finding of the European Central Bank (2013) study.

Firms with more liquidity were less likely to deleverage debt in the aggregate. This implies that firms were hoarding liquidity as a safeguard against uncertain financing conditions in the future. It also may be that creditors perceived the risk of default to be lower for firms with more liquidity and accordingly put less pressure on them to deleverage. The likelihood of deleveraging total debt was higher the greater was the initial debt burden This is in accordance with the 
proposition in corporate finance that a general rise of uncertainty and risk results in deleveraging by firms in order to converge towards a new target debt ratio.

\section{Deleveraging of business-to-business debt by continuing firms}

The results for deleveraging of total debt discussed above closely embody the patterns for the determinants of business-to-business debt deleveraging (column 3, Table 4). Thus, the influence of firm size, export orientation, ownership, profitability, productivity, liquidity, and initial level of debt leverage on the likelihood of business-to-business debt deleveraging was similar to that for total debt deleveraging.

However, there were notable differences in the influence of age, sectoral affiliation, and tangibility. The regression results indicate that young continuing firms were less severely impacted than mature continuing firms with regard to the utilization of business-to-business debt financing during the crisis period. The more mature firms (i.e., 15 years or older in age) were most likely to deleverage business-to-business debt. For age groups younger than 15 years, the impact of the crisis on deleveraging of business-to-business debt was smaller and broadly similar. This outcome is different from the Portuguese experience of younger firms being more severely impacted by the crisis than older firms with regard to debt financing (Teixeira and Pereira, 2016).

The sectoral influence on deleveraging of business-to-business debt was more varied than in the case of total debt deleveraging. Manufacturing firms were most prone to deleveraging businessto-business debt while firms engaged in accommodation and food services activities were least likely to deleverage. The construction and real estate sectors had no significant impact on deleveraging, although firms in these two sectors had the highest likelihood of exit.

Tangibility was not significantly related to deleveraging of business-to-business debt during the crisis period. This may be a reflection of collateral requirements not being a major factor in the extension of inter-firm credit.

\section{Deleveraging of bank debt by continuing firms}

The regression equation for deleveraging of bank debt is estimated by fitting a probit model with continuous endogenous regressors. A regular probit model would not be appropriate, because the 
regressor measuring bank debt-to-assets ratio in the deleveraging equation is endogenous and likely to be correlated with the error term. Only 45 percent of continuing firms in the sample had bank debt. Whether or not a firm had bank debt and the corresponding amount of bank debt are endogenously determined by demand and supply factors. ${ }^{14}$ The null hypothesis of nonendogeneity of the bank debt-to-asset ratio regressor is rejected on the basis of a Wald test of the exogeneity of the instrumented variable. In this subsection we identify the differences and similarities in deleveraging behaviour of firms between bank debt and business-to-business debt.

The influence of firm age was more conspicuous in the case of bank debt deleveraging. Whereas there was little difference between age groups below 15 years of age with regard to the impact of firm age on business-to business debt deleveraging, in the case of bank debt deleveraging there was a distinct negative relationship between age and deleveraging. In particular, firms younger than 5 years were least likely to deleverage, suggesting that obstacles to bank borrowing during the crisis were smaller for the younger firms. It may also be that the younger firms relied to a greater extent on bank debt than other forms of financing, and that this made them hesitant to reduce their exposure to bank debt.

Another difference entails the impact of firm size on deleveraging. Instead of a non-linear relationship observed in the case of business-to-business debt, there was a negative monotonic relationship between firm size and deleveraging of bank debt: micro firms were most likely to experience a reduction in bank debt leverage and large firms were least likely. This is perhaps attributable to a greater tightening of lending standards for the smaller firms, as they were more susceptible to the problem of information asymmetry during the crisis period.

In contrast to the pattern for business-to-business debt, state-owned firms were more likely to deleverage bank debt and large exporters were less prone to deleveraging bank debt compared to smaller exporters and non-exporters. This perhaps suggests that supply-side pressures from banks were more likely to be felt by state-owned firms and less likely to be felt by large exporters.

Sectoral influence on deleveraging was more diverse for bank debt than for business-to-business debt. The influence of manufacturing and accommodation and food services was statistically

\footnotetext{
${ }^{14}$ Unlike Demirguc-Kunt et al. (2015), we do not restrict the regression to firms that had strictly positive bank debt, as this would result in sample selection bias.
} 
significant and in a similar direction for business-to-business debt and bank debt. However, unlike in the case of business-to-business debt, firms in the construction and transport sector had a higher likelihood of bank debt deleveraging relative to firms in other sectors.

The influence of the financial conditions of Slovene firms at the time of the start of the global financial crisis on deleveraging behaviour was similar for business-to-business debt and bank debt.

\section{Deleveraging of non-bank financial debt by continuing firms}

The deleveraging pattern for non-bank financial debt (column 5, Table 4) was markedly different from that for business-to-business debt and bank debt with regard to firm size, sectoral affiliation and tangibility. Micro firms were less likely than larger firms to deleverage non-bank financial debt, whereas they had a higher likelihood of deleveraging both business-to-business debt and bank debt than larger firms. This perhaps suggests that micro firms were replacing business-tobusiness debt and bank debt by funding from non-bank financial sources. The coefficients on real estate, transport and storage, and trade are negative and significant for deleveraging of nonbank financial debt, but the influence of these sectors was not significant or was positive for deleveraging of business-to-business debt and bank debt. Firms with higher tangibility had a lower likelihood of deleveraging non-bank financial debt, but tangibility did not have a significant influence on deleveraging of business-to-business debt and bank debt. Unlike bank debt but similar to business-to-business debt, small and medium exporters were more likely to deleverage non-bank financial debt than large exporters and non-exporters.

\section{Robustness check: Multinomial probit estimates of firm exit and total debt deleveraging}

To assess the robustness of the results of the binomial probit models of firm exit and deleveraging of debt discussed above, we carried out a joint determination of the likelihood of exit and deleveraging of total debt for the entire sample of firms using a multinomial probit model. The three options faced by firms are exit, deleveraging of debt, and not deleveraging.

The results of the multinomial probit model presented in Table 5 reaffirm the significant determinants of firm exit and total debt deleveraging by continuing firms identified by the binary probit models. The contrasting patterns in the determinants of firm exit and deleveraging 
Table 5. Multinomial probit estimates of firm exit and deleveraging of total debt

\begin{tabular}{|c|c|c|}
\hline & Firm exit & $\begin{array}{l}\text { Deleveraging of } \\
\text { total debt by } \\
\text { continuing firms }\end{array}$ \\
\hline Independent variables & $\begin{array}{c}\text { Coefficient } \\
\text { (robust standard } \\
\text { error) }\end{array}$ & $\begin{array}{c}\text { Coefficient } \\
\text { (robust standard } \\
\text { error) }\end{array}$ \\
\hline & $(1)$ & (2) \\
\hline \multicolumn{3}{|l|}{ Firm age dummies ${ }^{l}$} \\
\hline Age 0 to 4 & $\begin{array}{c}0.3561 * * * \\
(0.0333)\end{array}$ & $\begin{array}{l}-0.0005 \\
(0.0323)\end{array}$ \\
\hline Age 5 to 9 & $\begin{array}{c}0.1588 * * * \\
(0.0361)\end{array}$ & $\begin{array}{c}0.0198 \\
(0.0346)\end{array}$ \\
\hline Age 10 to 14 & $\begin{array}{l}-0.0520 \\
(0.0412)\end{array}$ & $\begin{array}{l}-0.0540 \\
(0.0384)\end{array}$ \\
\hline \multicolumn{3}{|l|}{ Firm size dummies $^{2}$} \\
\hline Micro firms & $\begin{array}{c}0.4048 * * * \\
(0.1309)\end{array}$ & $\begin{array}{c}0.1641 \\
(0.1168)\end{array}$ \\
\hline Small firms & $\begin{array}{c}0.4011 * * * \\
(0.1329)\end{array}$ & $\begin{array}{c}0.3916^{* * *} \\
(0.1180)\end{array}$ \\
\hline Medium-sized firms & $\begin{array}{l}0.2715^{*} \\
(0.1411)\end{array}$ & $\begin{array}{c}0.3347 * * * \\
(0.1247)\end{array}$ \\
\hline \multicolumn{3}{|l|}{ Exporter status dummies ${ }^{3}$} \\
\hline Small exporter & $\begin{array}{c}-0.1843 * * * \\
(0.0371)\end{array}$ & $\begin{array}{c}0.2965 * * * \\
(0.0340)\end{array}$ \\
\hline Medium exporter & $\begin{array}{l}-0.0423 \\
(0.0432)\end{array}$ & $\begin{array}{c}0.1706 * * * \\
(0.0406)\end{array}$ \\
\hline Large exporter & $\begin{array}{c}0.0404 \\
(0.0471)\end{array}$ & $\begin{array}{c}0.1959 * * * \\
(0.0445)\end{array}$ \\
\hline \multicolumn{3}{|l|}{ Ownership dummies ${ }^{4}$} \\
\hline State-owned & $\begin{array}{c}-0.5849 * * \\
(0.2520)\end{array}$ & $\begin{array}{c}0.0254 \\
(0.1940)\end{array}$ \\
\hline Other mixed ownership & $\begin{array}{c}0.0627 \\
(0.0995)\end{array}$ & $\begin{array}{l}-0.1830^{*} \\
(0.0941)\end{array}$ \\
\hline
\end{tabular}


Table 5 (continued)

\begin{tabular}{|c|c|c|}
\hline & Firm exit & $\begin{array}{c}\text { Deleveraging of } \\
\text { total debt by } \\
\text { continuing firms }\end{array}$ \\
\hline \multirow[t]{2}{*}{ Independent variables } & $\begin{array}{c}\text { Coefficient } \\
\text { (robust standard } \\
\text { error) }\end{array}$ & $\begin{array}{c}\text { Coefficient } \\
\text { (robust standard } \\
\text { error) }\end{array}$ \\
\hline & (1) & (2) \\
\hline \multicolumn{3}{|l|}{ Industry dummies ${ }^{5}$} \\
\hline Manufacturing & $\begin{array}{c}-0.0852 * * \\
(0.0388)\end{array}$ & $\begin{array}{c}-0.0155 \\
(0.0361)\end{array}$ \\
\hline Construction & $\begin{array}{c}0.4052 * * * \\
(0.0420)\end{array}$ & $\begin{array}{l}-0.0310 \\
(0.0423)\end{array}$ \\
\hline Wholesale \& retail trade & $\begin{array}{c}0.0700 * * \\
(0.0341)\end{array}$ & $\begin{array}{l}-0.0581 * \\
(0.0323)\end{array}$ \\
\hline Transport \& storage & $\begin{array}{c}0.2557 * * * \\
(0.0606)\end{array}$ & $\begin{array}{c}0.0470 \\
(0.0584)\end{array}$ \\
\hline Accommodation \& food services & $\begin{array}{l}-0.0515 \\
(0.0622)\end{array}$ & $\begin{array}{c}-0.4867 * * * \\
(0.0620)\end{array}$ \\
\hline Real estate activities & $\begin{array}{c}0.2102 * * \\
(0.0838)\end{array}$ & $\begin{array}{c}-0.1844 * * \\
(0.0853)\end{array}$ \\
\hline Profitability (ROA) & $\begin{array}{c}0.0866 \\
(0.1339)\end{array}$ & $\begin{array}{c}0.1731 \\
(0.1404)\end{array}$ \\
\hline Total factor productivity & $\begin{array}{c}0.0003 \\
(0.0003)\end{array}$ & $\begin{array}{c}0.0008 * * * \\
(0.0003)\end{array}$ \\
\hline Tangibility & $\begin{array}{c}-0.0020 * * * \\
(0.0005)\end{array}$ & $\begin{array}{c}0.0042 * * * \\
(0.0005)\end{array}$ \\
\hline Liquidity & $\begin{array}{l}0.0026 * \\
(0.0014)\end{array}$ & $\begin{array}{c}-0.0182 * * * \\
(0.0046)\end{array}$ \\
\hline Total debt to assets ratio & $\begin{array}{c}0.0092 * * * \\
(0.0008)\end{array}$ & $\begin{array}{c}0.0060 * * * \\
(0.0008)\end{array}$ \\
\hline Constant & $\begin{array}{c}-0.9586 * * * \\
(0.1432)\end{array}$ & $\begin{array}{c}-0.3318^{* *} \\
(0.1291)\end{array}$ \\
\hline Log likelihood & & \\
\hline Chi-square & & \\
\hline $\mathrm{N}$ & & \\
\hline
\end{tabular}

${ }^{1}$ The base category is firm age 15 years or more.

${ }^{2}$ The base category is large firms.

${ }^{3}$ The base category is non-exporters.

${ }^{4}$ The base category is private ownership.

${ }^{5}$ The base category is NACE categories A, B, D, E, J, K, M, N, O, P, Q, R and S. $* * * \mathrm{p}<0.01,{ }^{* *} \mathrm{p}<0.05,{ }^{*} \mathrm{p}<0.1$ 
revealed by the multinomial probit exercise are also borne out by the comparison of the results of the binary probit models.

Sensitivity of regression estimates to the choice of sample period and measurement of profitability and debt leverage

We estimated a separate set of regressions to determine if some of the differences in the findings between our study and that of Damijan (2017) could be attributed to differences in the choice of sample period and measurement of variables. The qualitative aspects of the results are summarized in Table $6 .^{15}$

The choice of the sample time interval to define the crisis years makes a difference to the results obtained for the impact of profitability and initial debt burden on the deleveraging of non-bank financial debt. The coefficients on these two covariates switch their sign from negative to positive as the sample time period becomes longer (compare rows 1 and 2 with rows 5 and 6 , respectively, in Table 6). The results suggest that the more profitable and highly indebted firms were replacing business-to-business debt and bank debt by non-bank financial debt during the initial stages of the crisis covering the period 2008-2012. However, as the crisis period continued, such firms began to deleverage non-bank financial debt as well.

How profitability is measured makes a difference to some of the regression results. During the both the 2008-2012 and 2008-2014 sample periods, the rate of return on assets (ROA) and rate of return on equity (ROE) had similar qualitative impacts on the likelihood of firm exit and deleveraging of total debt and business-to-business debt. However, the impact on deleveraging of bank debt and non-bank financial debt was different for the two measures of profitability (compare row 1 with row 3, and row 5 with row 7 in Table 6).

The measure of initial debt leverage also makes a difference to the findings. Outstanding debt leverage had no significant impact on firm exit when measured as a ratio to EBDITA (the result obtained by Damijan, 2017), but had a positive and significant impact that is predicted in the corporate finance literature when measured as a ratio to assets (compare row 2 with row 4, and row 6 with row 8). For the equations on deleveraging of different categories of debt, the impact

${ }^{15}$ The full results of the regression equations for 2008-2012 are available from the corresponding author on request. 
Table 6. Sensitivity of estimates to sample period and measurement of profitability and debt leverage (sign and statistical significance of coefficients on the specified variables)

\begin{tabular}{|c|c|c|c|c|c|c|c|}
\hline & & & Firm exit & $\begin{array}{l}\text { Deleveraging } \\
\text { of total debt } \\
\text { by continuing } \\
\text { firms }\end{array}$ & $\begin{array}{l}\text { Deleveraging } \\
\text { of business-to- } \\
\text { business debt } \\
\text { by continuing } \\
\text { firms }\end{array}$ & $\begin{array}{l}\text { Deleveraging } \\
\text { of bank debt } \\
\text { by continuing } \\
\text { firms }\end{array}$ & $\begin{array}{l}\text { Deleveraging } \\
\text { of non-bank } \\
\text { financial debt } \\
\text { by continuing } \\
\text { firms }\end{array}$ \\
\hline \multirow[t]{6}{*}{ 2008-2014 } & \multirow[t]{3}{*}{$\begin{array}{c}\text { Row no. } \\
\text { (1) }\end{array}$} & ROA & not significant & +ve, significant & +ve, significant & +ve, significant & +ve, significant \\
\hline & & $\begin{array}{l}\text { Debt to } \\
\text { assets }\end{array}$ & +ve, significant & +ve, significant & +ve, significant & +ve, significant & +ve, significant \\
\hline & & $(N)$ & 28,330 & 19,358 & 19,354 & 19,358 & 19,358 \\
\hline & \multirow[t]{3}{*}{ (3) } & ROE & not significant & +ve, significant & +ve, significant & not significant & not significant \\
\hline & & $\begin{array}{l}\text { Debt to } \\
\text { EBDITA }\end{array}$ & not significant & not significant & not significant & +ve, significant & not significant \\
\hline & & $(N)$ & 27,627 & 19,001 & 18,997 & 11,059 & 13,587 \\
\hline \multirow[t]{5}{*}{ 2008-2012 } & \multirow[t]{3}{*}{$\begin{array}{c}\text { Row no. } \\
\text { (5) }\end{array}$} & ROA & -ve, significant & +ve, significant & +ve, significant & not significant & -ve, significant \\
\hline & & $\begin{array}{l}\text { Debt to } \\
\text { assets }\end{array}$ & +ve, significant & +ve, significant & +ve, significant & +ve, significant & -ve, significant \\
\hline & & $(N)$ & 28,330 & 20,915 & 20,911 & 12,305 & 14,509 \\
\hline & (7) & ROE & not significant & +ve, significant & +ve, significant & -ve, significant & not significant \\
\hline & (8) & $\begin{array}{l}\text { Debt to } \\
\text { EBITDA } \\
(N)\end{array}$ & $\begin{array}{r}\text { not significant } \\
27,627\end{array}$ & $\begin{array}{r}\text { not significant } \\
20,533\end{array}$ & $\begin{array}{r}\text { not significant } \\
20,529\end{array}$ & $\begin{array}{r}+v e, \text { significant } \\
12,207\end{array}$ & $\begin{array}{r}\text {-ve, significant } \\
14,283\end{array}$ \\
\hline
\end{tabular}

of the two alternative measures was quantitatively similar (positive and significant) only for the deleveraging of bank debt, irrespective of the sample time interval. For the shorter sample period, the impact was also similar for deleveraging of non-bank financial debt (negative and significant).

\section{Conclusions}

The onset of the global financial crisis resulted in an extensive shake out of firms in Slovenia and generated a prolonged deleveraging process. At the same time, however, many existing firms expanded operations by relying on borrowed funds, while new firms started operations. In this paper, we examine the impact of the global financial crisis on firm exit and corporate deleveraging in Slovenia during the crisis period covering 2008-2014 using firm-level data. 
Firms were categorized on the basis of whether they increased their leverage, decreased their leverage or ceased operation during the specified time interval, and the determinants of the probability of exit and decreasing leverage were estimated. We analysed the likelihood of deleveraging separately for business-to-business debt, bank debt, non-bank financial debt and total debt. The explanatory variables considered in the analysis are similar to those that have been highlighted in the corporate finance literature on capital structure. Overall, the results are broadly consistent with the theoretical models of the corporate finance literature.

The empirical results show that there were striking differences between firm exit and deleveraging with regard to the influences of covariates, and that the impact of the covariates on deleveraging differed considerably between different types of debt. Many of the covariates that were associated with the likelihood of firm exit in a particular direction were associated with deleveraging of debt in the opposite direction.

The younger and smaller firms were more vulnerable to the financial crisis and had a higher likelihood of exit. Firms in construction, real estate, accommodation and food services activities, and transport and storage suffered a higher rate of exit, while firms in the manufacturing sector were less likely to exit. State-owned firms displayed a lower probability of exit. Firms with a higher debt burden prior to the financial crisis were more at risk from the economic downturn.

As for deleveraging of aggregate total debt by continuing firms, there was no significant difference in the likelihood between firm age groups, although the likelihood was higher for small and medium-sized firms. The sectoral influence was less evident than in the case of firm exit, and the influence of state ownership was absent. Notably, although construction firms experienced a higher likelihood of exit, being in the construction sector did not have a significant influence on deleveraging of debt. In contrast to the pattern for firm exit, profitability, productivity and tangibility were all positively linked to deleveraging of total debt, a reflection of debt restructuring by firms in response to the heightened uncertainty and risk associated with the crisis. As in the case of firm exit, the likelihood of deleveraging total debt was higher the greater was the initial debt burden.

The results for the deleveraging of total debt represent the combined impact of the various covariates on the likelihood of deleveraging of business-to-business debt, bank debt and non- 
bank financial debt. There were notable differences between the three debt categories with regard to the impact of the covariates.

There was an inverted U-shaped relationship between firm size and the likelihood of deleveraging of business-to-business debt, whereas the likelihood of deleveraging bank debt decreased progressively with firm size. Micro firms were less likely than other size groups to deleverage non-bank financial debt. Sectoral influence on deleveraging was less evident for business-to-business debt than for bank debt and non-bank financial debt. Notably, construction firms had a higher likelihood of deleveraging bank debt than business-to-business debt and nonbank financial debt. The influence of the real estate sector on deleveraging of business-tobusiness debt and bank debt was not significant, but was negative and significant for deleveraging of non-bank financial debt.

The influence of profitability, productivity, liquidity and the initial level of debt burden on deleveraging likelihood was similar for all three categories of debt. The likelihood of deleveraging increased with higher profitability, higher productivity, and higher initial debt burden, and decreased with higher liquidity. In contrast, tangibility was not significantly related to deleveraging of business-to-business debt and bank debt, but was negatively associated with the likelihood of non-bank financial debt leveraging.

\section{References}

Banerjee, B. and Jesenko, M. 2014. Dynamics of firm-level job flows in Slovenia, 1996-2011. Comparative Economic Studies, 56 (1): 77-109.

Bole, V., Prašnikar, J. and Trobec, D. 2014. Policy measures in the deleveraging process: A macroprudential evaluation. Journal of Policy Modeling 36 (2): 410-432.

Bojnec, Š. and Xavier, A. 2007. Determinants of firm exit in Slovenian manufacturing. Industrial Management \& Data Systems 107 (5): 715-727.

Borio, C. E. V. 1990. Leverage and financing of non-financial companies: An international perspective. BIS Economic Papers no. 27. https://www.bis.org/publ/econ27.htm 
Bricongne, J-C., Fontagne, L., Gaulier, G., Taglioni, D. and Vicard, V. 2012. Firms and the global crisis: French exports in the turmoil. Journal of International Economics 87 (1):134-146.

Cuerpo, C., Drumond, I., Lendvai, J., Pontuch, P. and Raciborski, R. 2015. Private sector deleveraging in Europe. Economic Modelling 44: 372-383

Damijan, J. P. 2017. Corporate financial soundness and its impact on firm performance: implications for corporate debt restructuring in Slovenia. Post-Communist Economies 30 (1): 137. DOI: $10.1080 / 14631377.2017 .1398518$

Demirguc-Kunt, A., Martinez-Peria, M. S., and Tressel, T. 2015. The Impact of the Global Financial Crisis on Firms' Capital Structure. Policy Research Working Paper No. 7522, World Bank, Washington, DC. https://openknowledge.worldbank.org/handle/10986/23623 .

Duchin, R., Ozbas, O. and Sensoy, B. A. 2010. Costly External Financing, Corporate Investment, and the Subprime Mortgage Credit Crisis. Journal of Financial Economics 97 (3): 418-35

Dunne, T., Roberts, M. J. and Samuelson, L. 1988. Patterns of firm entry and exit in the U.S. manufacturing industries. RAND Journal of economics 19 (4): 495-515.

European Central Bank. 2013. Corporate finance and economic activity in the euro area. Structural Issues Report 2013, Occasional Paper Series No. 151, August. https://www.ecb.europa.eu/pub/pdf/scpops/ecbocp151.pdf

European Central Bank. 2014. Deleveraging patterns in the euro area corporate sector. $E C B$ Monthly Bulletin, February, 97-114.

Fort T. C., Haltiwanger, J., Jarmin, R. S. and Miranda, J. 2013. How firms respond to business cycles: The role of firm age and firm size. NBER Working Paper, 19134. http://www.nber.org/papers/w19134

Frank, M. Z. and Goyal, V. K. 2003. Testing the Pecking Order Theory of Capital Structure. Journal of Financial Economics 67 (2): 217-248. 
Frank, M. Z. and Goyal, V. K. 2008. Tradeoff and pecking order theories of debt. In E. Eckbo (Editor), The Handbook of Empirical Corporate Finance, vol. 2, pp. 135-202. Amsterdam: Elsevier Science.

Frank, M. Z. and Goyal, V. K. 2009. Capital structure decisions: which factors are reliably important? Financial Management 38 (1): 1-37

Gabrijelčič, M., Herman, U. and Lenarčič, A. 2016. Firm Performance and (Foreign) Debt Financing before and during the Crisis: Evidence from Firm-Level Data. Bank of Slovenia Working Papers 1/2016. https://bankaslovenije.blob.core.windows.net/publicationfiles/Firm_performance_and_(foreign)_debt_financing.pdf

Garrote, D., Llopis, J. and Vallés, J. 2013. Private-sector deleveraging channels: An international comparison. Banco de España Economic Bulletin No. 11, November.

Graham, J. R. and Leary, T. M. 2011. A review of empirical capital structure research and directions for the future. Annual Review of Financial Economics 3: 309-345.

Herwadkar, S. S. 2017. Corporate leverage in EMEs: Did the global financial crisis change the determinants? BIS Working Papers No. 681. https://www.bis.org/publ/work681.htm

Institute of Macroeconomic Analysis and Development (IMAD). 2014. Corporate indebtedness and deleveraging. Economic Issues. Ljubljana. pp: 73-101.

Iqbal, A. and Kume, O. 2014. Impact of Financial Crisis on Firms' Capital Structure in UK, France, and Germany. Multinational Finance Journal 18 (3/4): 249-280.

Jovanovic, B. 1982. Selection and the evolution of an industry. Econometrica 50(3): 649-670.

Kraus, A. and Litzenberger, R. H. 1973. A state-preference model of optimal financial leverage. Journal of Finance 28 (4): 911-922.

Landini, F., Arrighettic, A. and Lasagni, A. 2015. Economic crisis and firm exit: Do intangible matter? Working Paper 09/2015, LUISS School of European Political Economy. https://sep.luiss.it/sites/sep.luiss.it/files/EPE\%2010\%20Landini\%20et\%20al.pdf 
Manova, K., Wei, S-J., and Zhang, Z. 2015. Firm exports and multinational activity under credit constraints. The Review of Economics and Statistics 97 (3): 574-588.

Myers, S. C. 1984. The capital structure puzzle. Journal of Finance 39 (3): 575-592.

Myers, S. C. and Majluf, N. S. 1984. Corporate financing and investment decisions when firms have information that investors do not have. Journal of Financial Economics 13 (2): 187-221. https://doi.org/10.1016/0304-405X(84)90023-0

Myers, S. C. and Rajan, R. G. 1998. The paradox of liquidity. The Quarterly Journal of Economics 113 (3): 733-771.

Rajan, R. and Zingales, L. 1995. What do we know about capital structure? Some evidence from international data. Journal of Finance 50 (5): 1421-1460.

Santarelli, E., and Vivarelli, M. 2007. Entrepreneurship and the process of firms' entry, survival and growth. Industrial and Corporate Change 16 (3): 455-488.

Sila, U. (2015), Restoring the financial sector and corporate deleveraging in Slovenia. OECD Economics Department Working Papers, No. 1243, OECD Publishing, Paris. http://dx.doi.org/10.1787/5jrxml3x8vq0-en

Teixeira, J. C. A. and Pereira, O. M. 2016. The determinants of capital structure of Portuguese firms. CEEAplA Working Paper no. 01/2016, Centre of Applied Economics Studies of the Atlantic, University of the Azores, Portugal.

http://www.ceeapla.uac.pt/uploads/pms/attachments/Paper01-2016.pdf

Tripathy, N. and Asija, A. 2017. The impact of financial crisis on the determinants of capital structure of listed firms in India. Journal of International Business and Economy 18 (1): 101-121

van Doornmalen, R. 2013. Determinants of corporate capital structure during crisis periods: A study of capital structure in Europe. Master Thesis. Universiteit van Tilburg. http://arno.uvt.nl/show.cgi?fid=132729 


\section{Appendix}

Table: Entry, exit and deleveraging by firms

\begin{tabular}{|c|c|c|c|c|c|c|}
\hline Year & $\begin{array}{c}\text { No. of firms } \\
\text { in previous } \\
\text { year }\end{array}$ & $\begin{array}{l}\text { No. of } \\
\text { continuing } \\
\text { firms } \\
\text { (2) }\end{array}$ & $\begin{array}{l}\text { No. of new } \\
\text { entrants }\end{array}$ & $\begin{array}{l}\text { No. of exiting } \\
\text { firms }\end{array}$ & $\begin{array}{l}\text { No. of firms } \\
\text { in current } \\
\text { year } \\
(5)=(1)+ \\
(3)-(4)\end{array}$ & $\begin{array}{c}\text { No. of } \\
\text { continuing } \\
\text { firms that } \\
\text { deleveraged in } \\
\text { current year } \\
\text { (6) }\end{array}$ \\
\hline 2005 & 28,097 & 25,881 & 3,209 & 2,216 & 29,090 & 13,305 \\
\hline 2006 & 29,090 & 26,794 & 3,226 & 2,296 & 30,020 & 13,704 \\
\hline 2007 & 30,020 & 28,090 & 3,857 & 1,930 & 31,947 & 14,105 \\
\hline 2008 & 31,947 & 29,674 & 4,237 & 2,273 & 33,911 & 15,368 \\
\hline 2009 & 33,911 & 30,859 & 3,971 & 3,052 & 34,830 & 16,100 \\
\hline 2010 & 34,830 & 31,353 & 4,048 & 3,477 & 35,401 & 15,400 \\
\hline 2011 & 35,401 & 31,487 & 3,735 & 3,914 & 35,222 & 16,335 \\
\hline 2012 & 35,222 & 29,196 & 3,869 & 6,026 & 33,065 & 15,550 \\
\hline 2013 & 33,065 & 29,312 & 5,214 & 3,753 & 34,526 & 16,147 \\
\hline 2014 & 34,526 & 31,261 & 5,606 & 3,265 & 36,867 & 17,681 \\
\hline 2015 & 36,867 & 33,630 & 5,258 & 3,237 & 38,888 & 18,660 \\
\hline 2016 & 38,888 & 35,507 & 4,967 & 3,381 & 40,474 & 19,314 \\
\hline 2017 & 40,474 & 37,213 & 4,258 & 3,261 & 41,471 & 20,146 \\
\hline
\end{tabular}

Source: AJPES; authors' calculations. 